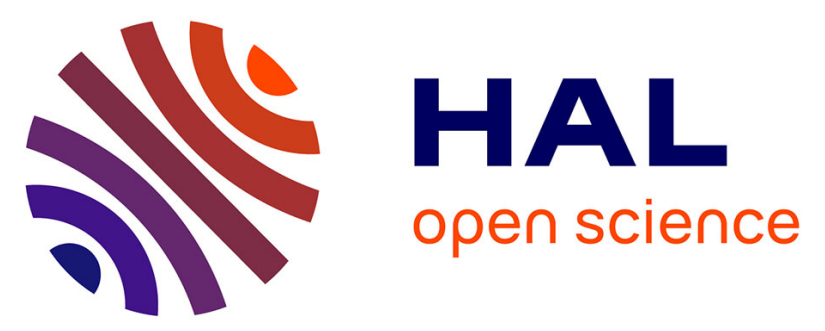

\title{
Modularity in Product-Service Systems: Literature Review and Future Research Directions
}

Maria Stoettrup Schioenning Larsen, Ann-Louise Andersen, Kjeld Nielsen, Thomas Ditlev Brunoe

\section{- To cite this version:}

Maria Stoettrup Schioenning Larsen, Ann-Louise Andersen, Kjeld Nielsen, Thomas Ditlev Brunoe. Modularity in Product-Service Systems: Literature Review and Future Research Directions. IFIP International Conference on Advances in Production Management Systems (APMS), Aug 2018, Seoul, South Korea. pp.150-158, 10.1007/978-3-319-99704-9_19 . hal-02164851

\section{HAL Id: hal-02164851 \\ https://hal.inria.fr/hal-02164851}

Submitted on 25 Jun 2019

HAL is a multi-disciplinary open access archive for the deposit and dissemination of scientific research documents, whether they are published or not. The documents may come from teaching and research institutions in France or abroad, or from public or private research centers.
L'archive ouverte pluridisciplinaire HAL, est destinée au dépôt et à la diffusion de documents scientifiques de niveau recherche, publiés ou non, émanant des établissements d'enseignement et de recherche français ou étrangers, des laboratoires publics ou privés. 


\title{
Modularity in Product-Service Systems: Literature Review and Future Research Directions
}

\author{
Maria Stoettrup Schioenning Larsen*[0000-0003-3396-4925], Ann-Louise Andersen ${ }^{[0000-0002-}$ \\ 7923-6301], Kjeld Nielsen ${ }^{[0000-0002-3720-167 \mathrm{X}]}$ and Thomas Ditlev Brunoe ${ }^{[0000-0002-9847-6562]}$ \\ Department of Materials and Production, Aalborg University, Aalborg, Denmark \\ schionningmegmail.com
}

\begin{abstract}
Modularity is a well-known concept that has been widely applied in both product and service design, respectively, for efficiently creating and offering variety to serve heterogeneous customer demand. However, the application of modularity in the design of a product-service system in which products and services are integrated is less addressed in previous research, despite servitization being a differentiating factor and promising strategy in many manufacturing companies. Thus, the purpose of this paper is to review state-of-the-art research on the development of modular product-service systems. The literature review assesses development methods for modular product-service systems proposed in previous research and categorizes these in regard to the development steps proposed, the research method applied, focus of the product-service systems, and the industry in which the research is conducted. Among others, the literature review concludes that research tends to focus on modular service development in the product-service system and the proposed methodologies for modular productservice system development mainly consists of four generic steps. Based on the findings of the literature review, areas of interest for future research are proposed.
\end{abstract}

Keywords. Modularity, Product-Service System, Servitization, Literature Review

\section{$1 \quad$ Introduction}

In today's fiercely competitive global market, customers are increasingly expecting offerings customized to their individual needs and preferences [1]. Manufacturing companies are therefore subject to requirements of serving highly heterogeneous demand as well as differentiating product offerings from competitors to stay competitive. As a result, many manufacturing companies have transitioned from solely producing and providing physical products towards implementing servitization strategies, where services are added to products in order to increase revenue, the value provided to customers and the customers' dependency towards the company [2,3]. However, with the increased tendency towards customization, servitizing companies must develop further to accommodate the diverse and personalized needs of the customers in an efficient 
way. Consequently, customizing the product-service system (PSS) to accommodate these needs is pertinent. Though, in the attempt to fulfill the individualized needs of customers, this often results in increased costs [1], which is undesirable. One method to tackle the paradox of customization and low costs is through modularization of the PSS $[4,5]$ in which the modular PSS is composed of standard modules, that are combined to meet the individualized needs of the customers [6]. Literature on modularity prescribes that companies can obtain benefits such as enhanced variety, higher flexibility, cost reductions, reduction of system complexity and improvement in product development time through modularity [7, 8]. Modularity has previously been applied in software development [9], product development [8-10], production system development $[8,9,11-13]$, organization and supply chain development [8], and service development $[8,9,14]$. Though, much research is directed towards either product modularity or service modularity, whereas less research exists in relation to modularity in a PSS environment [15] i.e. a modular architecture which covers both products and services in a PSS. According to Ulrich and Eppinger [10], a property of a modular architecture is that the interactions between modules are well-defined as opposed to an integral architecture. Therefore, since PSSs consist of integrated products and services, the development of a modular PSS should consider the mutual influencing factors among products and services in a PSS [16] for which reason existing research on developing product and service modularity, respectively, cannot be applied as they do not consider the interaction between products and services in PSSs. Thus, this paper seeks to investigate the scarce state-of-the-art literature in this field of research.

The paper is structured as follows: Section 2 presents the applied literature search methodology, Section 3 reveals the findings of the literature review, Section 4 discusses the findings of the literature review and research gaps are emphasized. Finally, Section 5 concludes on the findings of the research paper and proposes viable future research directions.

\section{Methodology}

The objective of this paper is to review existing research on development of PSS modularity. Therefore, a literature search protocol was developed to identify previous research contributions relevant for the literature review. The search protocol is illustrated in Fig. 1.

To uncover relevant literature for the review, a systematic literature search has been conducted. In the first phase of the literature search, four block search strings were searched through five scientific databases delimited to the time span from 2008 until present. If possible, the search was restricted to concerning abstract. Only peer-reviewed as well as English-language articles were selected for further assessment. The search engine results were excluded in two steps based on a qualitative screening of the following criteria: 1) modularity in a PSS or servitization context should be the central theme, and 2) development of a modular PSS should be in focus. In the first step of the exclusion process, the papers were reviewed and excluded based on title and abstract. 


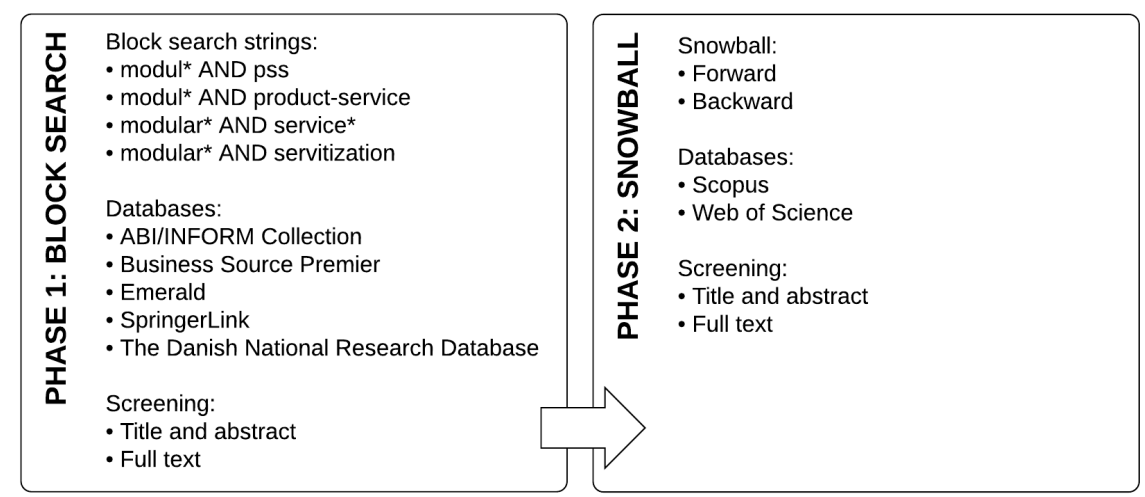

Fig. 1. Literature search protocol

In the second step, the papers, which passed the initial screening, were evaluated based on a full text screening. The excluded papers primarily addressed service modularity in service business and non-modular development of PSSs. The selected papers were afterwards subjected to a snowball approach both backward and forward in which the references in the articles identified in the first phase (backward) and references to these articles (forward) were screened. Firstly, the articles were assessed based on title and abstract. If the articles passed this screening, the full text was screened for relevance.

\section{$3 \quad$ Literature Review}

The literature search protocol resulted in 10 articles applicable for this paper, which were analyzed according to four parameters. Given that PSS is highly relevant in industry, the objective with the first two parameters is to clarify whether modularity of the PSS is equally relevant for all types of industries. Furthermore, it is desired to investigate to what extent state-of-the-art is linked to relevance in industry and thereby to what extent contributions from contextual understanding has been included in the development phase of the research. Therefore, the first parameter (Research's relation to industry) assesses the integration between research and industry in the applied research method, whereas the second parameter (Product/industry) assesses which product(s) or industry the research has been A) developed towards in general and B) validated on. To understand how modular PSSs are developed, steps in the proposed modular PSS development methodologies in the reviewed literature are identified. The third parameter (Steps in proposed modular PSS development methodology) therefore summarizes the main steps of the methods proposed for PSS modularity. This analysis is supported by an analysis of tools related to the proposed steps. Due to limited space, the results of this analysis have not been included in this paper. However, the list of tools related to the proposed methods for all reviewed articles can be obtained by inquiry to the authors. To identify the scope in the PSS of the proposed PSS development methodology and thereby identify whether the proposed development methodology considers the integration between product and services in the PSS, the focus in the PSS of the proposed method is assessed in the fourth parameter (Focus in PSS). The results 
are recapitulated in Table 1. The findings of the analyses are discussed in the next section.

Table 1. Results of the literature review

\begin{tabular}{|c|c|c|c|c|}
\hline Ref. & $\begin{array}{l}\text { Research's } \\
\text { relation to } \\
\text { industry }\end{array}$ & $\begin{array}{l}\text { Product/industry } \\
\text { A) Full paper, } \\
\text { B) Case study }\end{array}$ & $\begin{array}{l}\text { Steps in proposed modular PSS development } \\
\text { methodology }\end{array}$ & $\begin{array}{l}\text { Focus in } \\
\text { PSS }\end{array}$ \\
\hline [6] & $\begin{array}{l}\text { Validated in } \\
\text { case study }\end{array}$ & $\begin{array}{l}\text { A) None, B) Power } \\
\text { transformer }\end{array}$ & $\begin{array}{l}\text { 1. Service module partitioning "top-down", } 2 \text {. } \\
\text { Physical module partitioning "top-down", 3. Ser- } \\
\text { vice module partitioning "bottom-up", } 4 \text {. Establish } \\
\text { the modular platform of PSS }\end{array}$ & $\begin{array}{l}\text { PSS (product } \\
\text { and services) }\end{array}$ \\
\hline [17] & $\begin{array}{l}\text { Validated in } \\
\text { case study }\end{array}$ & $\begin{array}{l}\text { A) Product with many } \\
\text { parts and advanced } \\
\text { technologies, B) Air- } \\
\text { material services }\end{array}$ & $\begin{array}{l}\text { 1. Value demands of customers, } 2 \text {. Service modu- } \\
\text { larity, 3. Service configuration }\end{array}$ & $\begin{array}{l}\text { Service in } \\
\text { PSS }\end{array}$ \\
\hline [18] & $\begin{array}{l}\text { Validated in } \\
\text { case study }\end{array}$ & $\begin{array}{l}\text { A) None, B) Compres- } \\
\text { sor rotor }\end{array}$ & $\begin{array}{l}\text { 1. Service components identification, } 2 \text {. Correla- } \\
\text { tion analysis for service components, } 3 \text {. Service } \\
\text { module partition }\end{array}$ & $\begin{array}{l}\text { Service in } \\
\text { PSS }\end{array}$ \\
\hline [19] & $\begin{array}{l}\text { Validated in } \\
\text { case study }\end{array}$ & $\begin{array}{l}\text { A) Complex machines, } \\
\text { B) Machining manu- } \\
\text { facturer }\end{array}$ & $\begin{array}{l}\text { 1. Analysis of market and customer requirements, } \\
\text { 2. Concept development, } 3 \text {. Establish optimal busi- } \\
\text { ness model, } 4 \text {. Service module design, } 5 \text {. Delivery } \\
\text { and implement service }\end{array}$ & $\begin{array}{l}\text { Service in } \\
\text { PSS }\end{array}$ \\
\hline [16] & $\begin{array}{l}\text { Validated in } \\
\text { case study }\end{array}$ & $\begin{array}{l}\text { A) None, B) Civil air- } \\
\text { craft manufacturer }\end{array}$ & $\begin{array}{l}\text { 1. Decompose functions of PSS into functional } \\
\text { modules, } 2 \text {. Simultaneous development of product } \\
\text { modularization and service modularization based } \\
\text { on functional modules }\end{array}$ & $\begin{array}{l}\text { PSS (product } \\
\text { and service) }\end{array}$ \\
\hline [20] & $\begin{array}{l}\text { Validated in } \\
\text { case study }\end{array}$ & $\begin{array}{l}\text { A) None, B) Power } \\
\text { transformer }\end{array}$ & $\begin{array}{l}\text { 1. Collect service needs, } 2 \text {. Determine service de- } \\
\text { mand category, } 3 \text {. Find solutions for each service } \\
\text { need and build rough structure, } 4 \text {. Configure and } \\
\text { plan principal solution, } 5 \text {. Service solution evalua- } \\
\text { tion }\end{array}$ & $\begin{array}{l}\text { Service in } \\
\text { PSS }\end{array}$ \\
\hline [21] & $\begin{array}{l}\text { Validated in } \\
\text { case study }\end{array}$ & $\begin{array}{l}\text { A) None, B) Engineer- } \\
\text { ing machine manufac- } \\
\text { turer }\end{array}$ & $\begin{array}{l}\text { 1. Determine PSS family functions, } 2 \text {. Modularize } \\
\text { PSS, } 3 \text {. Assign and integrate modules }\end{array}$ & $\begin{array}{l}\text { PSS (product } \\
\text { and services) }\end{array}$ \\
\hline [4] & $\begin{array}{l}\text { Industrial re- } \\
\text { search }\end{array}$ & $\begin{array}{l}\text { A) None, B) Elevator } \\
\text { manufacturer }\end{array}$ & $\begin{array}{l}\text { 1. PSS requirements identification and analysis, } 2 \text {. } \\
\text { Technical attributes and conflicts solving, } 3 \text {. PSS } \\
\text { modularization, } 4 \text {. PSS configuration and concept } \\
\text { selection }\end{array}$ & $\begin{array}{l}\text { Service in } \\
\text { PSS }\end{array}$ \\
\hline [22] & $\begin{array}{l}\text { Validated in } \\
\text { case study }\end{array}$ & $\begin{array}{l}\text { A) None, B) Elevator } \\
\text { manufacturer }\end{array}$ & $\begin{array}{l}\text { 1. Describe customers' needs and wants, } 2 \text {. Deter- } \\
\text { mine level of granularity, } 3 \text {. Gather service com- } \\
\text { ponents, } 4 \text {. Assign interactions, } 5 \text {. Create service } \\
\text { modules }\end{array}$ & $\begin{array}{l}\text { Service in } \\
\text { PSS }\end{array}$ \\
\hline [23] & $\begin{array}{l}\text { Validated in } \\
\text { case study }\end{array}$ & $\begin{array}{l}\text { A) CNC, B) Economi- } \\
\text { cal turning center }\end{array}$ & $\begin{array}{l}\text { 1. Physical module division, } 2 \text {. Service module di- } \\
\text { vision, 3. Integration of modular PSS, } 4 \text {. Configu- } \\
\text { ration modeling of PSS }\end{array}$ & $\begin{array}{l}\text { PSS (product } \\
\text { and service) }\end{array}$ \\
\hline
\end{tabular}

In the reviewed literature, services are defined based on their relations and dependencies to products $[4,6,16-19,23]$. This distinction has implied, that some authors use terms like product-service [17], product-extension service [18] and industrial service [19] when referring to services in a product-service system, whereas other authors have incorporated product and service into one, common term, e.g. integrated service product [6] or integrated service-oriented product [23]. In the remaining of this paper, all 
these definitions will be subject to the term service. When referring to PSS, a reference is made to those systems consisting of one product and one or more services.

\section{Discussion}

\subsection{Development Methodology, Tools, and Focus in Product-Service System}

The majority of the research concentrates on service modularity in PSS, which might be a result of researchers adapting service modularity research from a service business context to a PSS context instead of letting the interaction between products and services being the primary subject. Besides, since service modularity is a newer field of research as opposed to product modularity [15], this may also explain why researchers have focused their attention on service modularity in PSS and not modularization of both products and services. Moreover, since product modularity is more widespread, researchers may also think of product modularity as a step, which many companies have already gone through and that service modularity is considered the next step after product modularity and thereby see product and service modularity as two separate, yet consecutive development phases, just like the development of a PSS in which the products are designed first, followed by the design of services related to the products. The increased focus on services in PSS is also reflected in that the proposed methods in most of the analyzed articles mainly consist of four generic steps which are all related to service modularity in the PSS instead of both service and product modularity in the PSS. The generic steps reflect the development methodology of modular products as proposed by Ericsson and Erixon [24]. The four generic steps can be described as follows. First, customer requirements are identified to ensure that the customer's needs are met [20]. In the second step, customer requirements are translated into service specifications which can be understood and used in the design phase [4] of the service modularization, which is the third step. At last, the module structure is defined in a configuration model supporting the service configuration, which composes the fourth step.

A few articles $[18,23]$ analyze the company's existing services and use these as input for modularization, and thereby assume that existing services fulfill customers' needs. According to Salvador et al. [25], one of three fundamental capabilities for mass customization is to identify the attributes of which customer needs diverge, and it might therefore be questioned whether one would achieve good results with the use of existing services as input, since it might be difficult to identify the attributes where customers' needs diverge. Though, the generic method reflects the three fundamental capabilities of mass customization as proposed by Salvador et al. [25], where solution space development is reflected in the first two steps. Robust process design is considered through the third step, and choice navigation is handled in the last. This is not surprising, since the three capabilities determine a company's ability to mass customize its offerings [25] and therefore are essential for the development of a modular PSS. However, only few articles $[4,17,20]$ account for all four steps and most articles therefore do not consider all three capabilities in the proposed development methods. Further research may therefore focus on methods in which all four steps are considered. 
Some articles recommend tools for those steps which are included in the proposed development methods. This is not unexpected since the research field is situated between research on service modularity in service business and research on product modularity. A minority of the research [6, 23], which takes both product and service modularity into consideration combines the separate product and service modules into one common module, which reflects the integration existing between products and services in a PSS. However, the reusability of modules by applying this method is questioned, since the opportunity to reuse modules seems to disappear which entails that a new module design phase must be initiated whenever new products or services are to be developed instead of reusing existing modules, which is deemed to be one of the main benefits of modularity [7, 24, 25]. As future research area, the field of integration between product and service modularity in PSS therefore seems promising.

As seen in Table 1, most reviewed research solely focuses on one service in the PSS. In addition to this, none of the analyzed research contributions considers services across products in PSSs. Applying such narrow scope in the development of modules, decreases the reusability of modules in other cases, since the modules have been developed for one specific case. Furthermore, as research tends to focus on a single service, too much complexity might have been omitted from the development process. For instance, the production process of a service is easy to define when only one service is taken into consideration in the modularization process since the production process of the service is defined in the development of the modules, whereas the production process of a service which is combined by few, standard modules from a larger pool of modules are probably not possible to predefine as it will depend on the main goal of the customer's need to be satisfied. Broadening the scope of services in future research might therefore contribute with valuable insight in the literature.

\subsection{Research's Relation to Industry, and Product/Industry Focus}

A tendency exists in the literature to research related to complex products. Case studies and specifications of research have been aimed at companies producing and selling products which are considered complex in their structure such as machines, elevators, and power transformers. Thus, since services are related to products in this field of research, research on less complex product structures may benefit the research field.

The majority of the concepts proposed in literature are developed from a theoretical point of view and afterwards validated in a case study, which means that contributions from contextual understanding in the development phase of the research is missing. Therefore, future research might benefit from applying an industrial research strategy to contribute with knowledge of not only modular PSS development, but also on how these can be effectively developed in different industrial contexts.

\section{Conclusions}

Servitizing companies must adapt to the market's increasing expectations of customized and personalized solutions. A method to accommodate these requirements is 
through modularization of the company's PSS. Therefore, the aim of this research was to review existing research on developing a modular PSS. The proposed methods in reviewed research mainly consist of four generic steps which are: 1) Identify customer requirements, 2) translate customer requirements into service specifications, 3) construct services modules, and 4) setup configuration model. Though, only limited research proposes development methods in which all four steps are considered. Thus, future research should contribute with methods, which consider all four steps in a structured way including supportive tools for each step. Furthermore, a lack of research on integration between product and service modularity in a PSS context has been identified which therefore form basis for further research. Focus in existing research has been aimed at modularizing one service in a PSS and further research in PSS modularity may therefore benefit from broadening the scope and considering multiple products and services. So far, research has had a tendency towards being related to complex products and composed from a theoretical point of view. Therefore, future research may benefit from being conducted on less complex products and from an industrial point of view.

\section{References}

1. Gilmore, J.H., Pine, B.J.: Markets of one: creating customer-unique value through mass customization. 1st edn.Harvard Business School Press, Boston (2000).

2. Baines, T., Lightfoot, H., Benedettini, O., Kay, J.M.: The servitization of manufacturing: A review of literature and reflection on future challenges. Journal of Manufacturing Technology Management 20, 547-567 (2009).

3. Curiazzi, R., Rondini, A., Pirola, F., Ouertani, M-Z., Pezzotta, G.: Process Standardization to Support Service Process Assessment and Re-engineering. Procedia CIRP 47, 347-352 (2016).

4. Song, W., Sakao, T.: A customization-oriented framework for design of sustainable product/service system. Journal of Cleaner Production 140, 1672-1685 (2017).

5. Lyons, A.C., Mondragon, A.E.C., Piller, F., Poler, R.: Mass Customisation: A Strategy for Customer-Centric Enterprises. In: Customer-Driven Supply Chains, pp. 71-94. Springer, London (2012).

6. Li, H., Ji, Y., Gu, X., Qi, G., Tang, R.: Module partition process model and method of integrated service product. Computers in Industry 63, 298-308 (2012).

7. Storbjerg, S.H., Brunoe, T.D.: Analysis of Enabling Factors in Realizing Modularization Benefits. In: Anisic, Z., Freund, R. (eds.) Proceedings of the 5th International Conference on Mass Customization and Personalization Central Europe, MCP-CE 2012, LNCS, pp. 104-111 (2012).

8. Bask, A., Lipponen, M., Rajahonka, M., Tinnilä, M.: The concept of modularity: diffusion from manufacturing to service production. Journal of Manufacturing Technology Management 21, 355-375 (2010).

9. Voss, C.A., Hsuan, J.: Service architecture and modularity. Decision Sciences 40, 541569 (2009).

10. Ulrich, K.T., Eppinger, S.D.: Product Design and Development, 6th edn. McGraw-Hill Education - Europe, London (2015). 
11. Andersen, A.-L., Brunoe, T.D., Nielsen, K., Rösiö, C.: Towards a generic design method for reconfigurable manufacturing systems. Journal of Manufacturing Systems 42, 179195 (2017).

12. Bejlegaard, M., Brunoe, T.D., Nielsen, K.: Application of Module Drivers Creating Modular Manufacturing Equipment Enabling Changeability. Procedia CIRP 52, 134 138 (2016).

13. Joergensen, S.N., Nielsen, K., Joergensen, K.A.: Reconfigurable manufacturing systems as an application of mass customisation. International Journal of Industrial Engineering and Management 1(3), 111-119 (2010).

14. Sundbo, J.: Modulization of service production and a thesis of convergence between service and manufacturing organizations. Scandinavian Journal of Management 10, 245-266 (1994).

15. Brax, S.A., Bask, A., Hsuan, J., Voss, C.: Service modularity and architecture - an overview and research agenda. International Journal of Operations \& Production Management 37, 686-702 (2017).

16. Wang, P.P., Ming, X.G., Li, D., Kong, F.B., Wang, L., Wu, Z.Y.: Modular development of product service systems. Concurrent Engineering Research and Applications 19, 8596 (2011).

17. Wang, P.P., Ming, X.G., Wu, Z.Y., Zheng, M.K., Xu, Z.T.: Research on industrial product-service configuration driven by value demands based on ontology modeling. Computers in Industry 65, 247-257 (2014).

18. Song, W., Wu, Z., Li, X., Xu, Z.: Modularizing product extension services: An approach based on modified service blueprint and fuzzy graph. Computers and Industrial Engineering 85, 186-195 (2015).

19. Yu, M., Zhang, W., Meier, H.: Modularization based design for innovative productrelated industrial service. In: Proceedings of 2008 IEEE International Conference on Service Operations and Logistics, and Informatics, IEEE/SOLI 2008, LNCS, vol. 1, pp. 48-53, IEEE, Beijing (2008).

20. Li, H., Ji, Y., Li, Q., Yang, M., Evens, S.: A methodology for module portfolio planning within the service solution layer of a product-service system. International Journal of Advanced Manufacturing Technology, 1-22 (2018).

21. Chen, D., Chu, X., Li, Y.: Applying Platform Design to Improve Product-Service Systems Collaborative Development. In: Camarinha-Matos L.M., Afsarmanesh H. (eds) Collaborative Systems for Smart Networked Environments. PRO-VE 2014., LNCS, vol. 434, pp. 107-116. Springer, Berlin, Heidelberg (2014).

22. Sakao, T., Song, W., Matschewsky, J.: Creating service modules for customising product/service systems by extending DSM. CIRP Annals - Manufacturing Technology 66, 21-24 (2017).

23. Sheng, Z., Liu, C., Song, J., Xie, H.: Module division and configuration modeling of $\mathrm{CNC}$ product-service system. Proceedings of the Institution of Mechanical Engineers, Part C: Journal of Mechanical Engineering Science 231, 494-506 (2017).

24. Ericsson, A., Erixon, G.: Controlling Design Variants. 1st edn. Society of Manufacturing Engineers, Southfield (1999).

25. Salvador, F., de Holan, P.M., Piller, F.T.: Cracking the Code of Mass Customization. MIT Sloan Management Review 50, 71-78 (2009). 